ekonomichnoji bezpeky upravlinnja pidpryjemstvom [Controlling the economic security of enterprise management]. Bulletin of Chernihiv State Technological University: collection. Vol. 44., pp. 15-19

13. Pilevych D.S. (2017) Sutnistj finansovo-ekonomichnoji bezpeky pidpryjemstva ta rolj kontrolinghu $\mathrm{v}$ jiji zabezpechenni [The essence of financial and economic security of the enterprise and the role of controlling in its provision]. BUSINESS INFORM. Vol. 2, pp. 337-342

14. Osmanagić Bedenik, N. and Lalovac, B. (2007), Kontroling - faktor poslovnog uspjeha na primjeru hotelskih poduzeća, Acta turistica, 19 (1), pp. 83-99.

15. Malyarets L., Draskovic M., Babenko V., Kochuyeva, Z. \& Dorokhov O. (2017) Theory and practice of controlling at enterprises in international business. Economic Annals-XXI, 165(5-6), 90-96.

16. Mishchenko S.N. (2004) Sistema obespecheniya ekonomicheskoy bezopasnosti organizatsii [The system of ensuring the economic security of the organization] ( $\mathrm{PhD}$ Econ). Rostov on Don: Don State Technical University.
17. Oneshko S.V., Kukshynova O.O. (2018) Ekonomiko-pravovi aspekty formuvannja dokhodiv pidpryjemstv portovoji dijaljnosti [Economic and legal aspects of the formation of incomes of enterprises of port activity]. The bulletin of Transport and Industry Economics. No. 64, pp. 300-310

18. Oneshko S., Ilchenko S. (2017) Financial monitoring of the port industry companies on the basis of risk-oriented approach. Investment Management and Financial Innovations. Volume 14, Issue \#1, pp. 191-199.

19. Zhikhareva V. (2012) Qualitative risk assessment in port activity. Economic innovation. vol. 50, pp. 225-230.

20. Bojko M.O. (2016) Ryzyky styvidornoji kompaniji v systemi zabezpechennja ekonomichnoji bezpeky [The risks of a stevedoring company in the system of economic security]. Young scientist. Vol. 9 (36), pp. 5-10.

21. Loh Hui Shan \& Thai Vinh V. (2015) Management of disruptions by seaports: preliminary findings. Asia Pacific Journal of Marketing and Logistics. Vol 27 (1), 146-162.

\title{
СИСТЕМА СТРАТЕГІЧНОГО КОНТРОЛІНГУ В АСПЕКТІ ЗАБЕЗПЕЧЕННЯ АНТИКРИЗОВОГО УПРАВЛІННЯ ПІДПРИЕМСТВОМ
}

\author{
Проценко В.М., к.е.н., зав. сектору контролю за виконанням \\ ліцензійних вимог (Департамент атестації кадрів вищої кваліфікації та \\ ліцензування Міністерства освіти і науки Украӥни)
}

В роботі проведено аналіз причин виникнення кризових явищ на всіх рівнях начіональної економіки. В рамках системи управління діяльністю підприємства розглянуто порівняльну характеристику основних елементів антикризового управління та стратегічного контролінгу. Доведено та обтрунтовано місие стратегічного контролінгу в антикризовому управлінні підприємством, як складової загальної системи управління підприємством, пропоновані інструменти стратегічного контролінгу в антикризовому управління підприємством.

Ключові слова: антикризове управління, стратегічний контролінг, криза, інструменти стратегічного контролінгу, підприємство, система управління. 


\section{СИСТЕМА СТРАТЕГИЧЕСКОГО КОНТРОЛЛИНГА В АСПЕКТЕ ОБЕСПЕЧЕНИЯ АНТИКРИЗИСНОГО УПРАВЛЕНИЯ ПРЕДПРИЯТИЕМ}

\section{Проценко В.Н., к.э.н., зав. сектором контроля за выполнением лицензионных требований (Департамент аттестации кадров высией квалификации и лицензирования Министерства образования и науки Украины)}

В работе проведен анализ причин возникновения кризисных явлений на всех уровнях национальной экономики. В рамках системы управления деятельностью предприятия рассмотрена сравнительная характеристика основных элементов антикризисного управления и стратегического контроллинга. Доказано и обосновано место стратегического контроллинга в антикризисном управлении предприятием, как составляющей общей системы управления предприятием, предлагаемые инструменты стратегического контроллинга в антикризисном управления предприятием.

Ключевые слова: антикризисное управление, стратегический контроллинг, кризис, инструменты стратегического контроллинга, предприятие, система управления.

\section{STRATEGIC CONTROLLING SYSTEM IN THE ASPECT ENSURING ANTI-CRISIS MANAGEMENT THE ENTERPRISE}

\section{Protsenko V.N., Ph.D., Head the Sector for Monitoring the Compliance with the Licensing Requirements (Department Attestation High Qualifications and Licensing Personnel the Ministry Education and Science of Ukraine)}

The results of any enterprise activity depends largely on its management system. Crisis conditions of economic activity at all levels of the national economy require the introduction of crisis management measures and directions that would enable enterprises to be more adapted to modern conditions.

One of the measures to adapt to the crisis conditions in the system of crisis management is the introduction of control system, and one of its components - strategic control. The research has conducted a comparative description of the main elements of the system of crisis management and the place of strategic control as an integral part of it: goals, tasks, functions, principles and their tools. It has been proved that both the system of crisis management and strategic control have common principles of management, functions and aims at achieving the unified goal of functioning of enterprises in crisis conditions of management, namely: preservation of the current state of enterprise development; preventing the manifestation or aggravation of the crisis.

Therefore, strategic control should become one of the most effective tools of crisis management in the general system of enterprise management, addressing the issues of adaptation of the operation of enterprises in crisis conditions.

Key words: crisis management, strategic controlling, crisis, strategic controlling tools, enterprise, management system.

Постановка проблеми. Сучасний період економічних відносин характеризується складними соціально- економічними умовами невизначеності та динамічності зовнішнього середовища в яких функціонують вітчизняні 
підприємства. За даних умов виникають чинники зовнішнього впливу, що відображаються на результатах внутрішнього характеру, дестабілізуючи діяльність підприємств та призводять до кризових явищ. Тому, головною умовою забезпечення їх стійкості, конкурентоспроможності та адаптації до кризових умов $€$ використання режиму антикризового управління. Це можливо за умов поєднання прогнозування, попередження, та впровадження заходів подолання кризи, що одночасно дозволить утримувати стабільне функціонування підприємства.

Таким чином, підвищується зацікавленість до розробки напрямів антикризового управління підприємствами 3 використанням прогресивних інноваційних заходів управління діяльністю підприємств через впровадження системи контролінгу. При цьому, заходи до впровадження не повинні порушувати, а тільки підвищувати рівень адаптації підприємства до впливу вищеназваних факторів та бути адекватними в ринкових умовах.

Аналіз останніх досліджень i публікацій. Останнім часом, внаслідок наявності кризових явищ на всіх рівнях світової та національної економічних систем, багатьма науковцями розглядаються заходи антикризового управління такими, як: В.В. Коваленко, M.B. Суганяка, B.I. Фучеджи [3], О.О.Мельниченко [5], Ус Ю.В. [9], Н.В. Якименко-Терещенко, О.I. Палієнко [10] та ін. Вітчизняними та закордонними науковцями розглядаються причини виникнення дестабілізації діяльності підприємств, заходи попередження кризи та напрями її подолання.

Окремо науковцями розглядаються питання впровадження системи контролінгу в діяльність вітчизняних підприємств, їх переваги, недоліки, складові елементи. До них можна віднести: Ю.М. Великого, В.В. Прохорову [1,7],
Н.В. Сабліну [1], В.В. Ходзицьку [7], Чобіток B.I. [7] та ін.

Виділення невирішених частин загальної проблеми. Але, на сьогодні не спостерігається застосування системи стратегічного контролінгу як напряму, який спроможний поєднати попередження кризових умов 3 елементами контролю за заходами подолання кризи та адаптації підприємств в кризових умовах із збереженням нормального їх функціонування.

Метою дослідження є виявлення та обгрунтування місця стратегічного контролінгу в системі антикризового управління підприємством.

Виклад основного матеріалу дослідження. Особливістю сучасного періоду функціонування підприємств $\epsilon$ наявність кризових явищ на всіх рівнях національної економіки. Вітчизняні підприємства не в змозі й сьогодні оцінити рівень впливу кризових явищ на результати своєї діяльності, що в подальшому може привести до негативних наслідків, а ж до банкрутства. Тобто в системі управління будь-яким підприємством необхідно більше уваги приділяти впровадженню напрямів та заходів антикризового управління.

Більшість авторів, які займаються питаннями антикризового управління підприємствами, серед основних причин виникнення кризових явищ в економіці виділяють: вплив міжнародних стандартів та процесів, що відбуваються на світовому фінансовому ринку; вплив внутрішньо національних факторів розвитку як економічних процесів, так і фінансової системи; конкурентна позиція суб'єктів економічної діяльності на ринку послуг; організація фінансового менеджменту та iн. [3].

Автори стверджують, що виникнення кризи і її розвиток - не випадковість, а закономірність, що вимагає нових підходів до дослідження причин його виникнення та розвитку. Своєчасність виявлення i встановлення можливих 
причин дозволять стабільно функціонувати і розвиватися підприємству [3].

Кризи сьогодні мають різноманітні напрями, причини їх виникнення та вплив на діяльність підприємств. Тому важливим постає питанням їх визначення, ідентифікації для подальшого антикризового управління підприємствами та адаптації їх функціонування в зазначених умовах.

Так, наприклад, А. Ковальов описує стадії кризи наступним чином [2]:

- потенційна криза - наявність можливості кризи, але відсутність достовірних симптомів кризи;

$$
\text { прихована криза }
$$

характеризується прихованою наявною кризою, вплив якої не може бути визначено наявним інструментарієм;

- гостра криза, яку можна подолати

- безпосередне відчуття негативного впливу;

- гостра криза, яку не можна подолати - посилення інтенсивності направленого проти банку негативного впливу, при якому вимоги для подолання кризи значно перевищують наявний потенціал.

У зв'язку 3 цим деякими науковцями, а саме Е.М. Коротковим у [4] сформульовано основні положення системи управління в умовах невизначеності. Вони передбачають наступне:

- суб'єкт економічної діяльності це відкрита система, яка розглядається в єдності факторів внутрішнього i зовнішнього середовища;

- орієнтація не на обсяги, а на якість продукції та послуг, задоволення споживачів;

- ситуаційний підхід до

управління, визнання важливості швидкості i адекватності реакцій, які забезпечують адаптацію до умов існування підприємства;

- система управління, орієнтована на підвищення ролі організаційної культури i нововведень, на мотивацію працівників і новий стиль керівництва.

Зважаючи на вищесказане, можна зробити висновок, що використання традиційних методів управління діяльністю підприємства в кризових умовах неможливо за рядом особливих причин. Тому в цьому випадку потрібні інші підходи до управління та прийняття таких рішень, які могли б в найкоротші терміни змінити хід подій, зупинити або пом'якшити наближення кризи. Антикризове управління повинно орієнтуватися на інноваційні напрями та заходи управління. Одним з таких напрямів $\epsilon$ впровадження в систему антикризового управління системи контролінгу i, як однією 3 iï форм - стратегічного контролінгу. Інструменти стратегічного контролінгу, які застосовуються багатьма провідними економічно розвинутими країнами світу, дозволяє на стадії формування стратегії розвитку підприємства передбачати та попереджувати вплив кризових явищ на діяльність окремого підприємства та пов'язані із значними змінами в умовах їх діяльності, а також 3 непередбачуваністю ситуації та іiі невизначеністю.

Основне спрямування системи антикризового управління підприємства в загальній системі управління повинно бути націлено на:

- орієнтацію на підвищення якості продукції (товарів, послуг), що є однією 3 цілей управління, та визначає зміст, особливість та ефективність функціонування підприємства;

- орієнтацію на впровадження інноваційних технологій, продуктів, системи управління, що, в свою чергу, надасть змоги адаптувати діяльність підприємства та систему його управління до нових умов;

- орієнтацію на диверсифікацію та впровадження новітніх методів управління, що дозволить передбачувати кризові явища та їх вплив на діяльність підприємства. 
Зміни в управлінні абсолютно очевидні, вони викликані потребами розвитку підприємств. Специфіку антикризового управління характеризують двома тезами:

- по-перше, це комплекс профілактичних заходів, спрямованих на недопущення кризи: системний аналіз сильних та слабких сторін суб'єкта економічної діяльності, оцінка ймовірності банкрутства, управління ризиками (виявлення, оцінка та нейтралізація), упровадження системи запобіжних заходів тощо.

- по-друге, це система управління фінансами, спрямована на виведення суб'єктів економічної діяльності 3 кризи, зокрема за допомогою санації чи реструктуризації суб'єкта господарювання [3].

Таким чином, антикризове управління необхідно розглядати як підсистему загальної системи управління підприємствами, головним завданням якого $\epsilon$ своєчасне діагностування передкризового стану підприємства i прийняття необхідних заходів щодо попередження кризи за допомогою системи стратегічного контролінгу. Для визначення основних елементів системи антикризового управління та місця стратегічного контролінгу як складової іiі частини, в таблиці проведено систематизація: мети, завдання, функцій, принципів та їх інструментів.

Порівняльна характеристика основних елементів антикризового управління та стратегічного контролінгу"

\begin{tabular}{|c|c|c|}
\hline $\begin{array}{c}\text { Основні } \\
\text { елементи }\end{array}$ & Система антикризового управління & Стратегічний контролінг \\
\hline 1 & 2 & 3 \\
\hline Мета & \begin{tabular}{lcr} 
збереження & поточного & стану \\
розвитку & \multicolumn{1}{c}{ підприємства; } \\
недопущення & прояву \\
загострення & кризи; виведення \\
підприємства із кризового стану; \\
уникнення ліквідації підприємства, \\
яке перебуває на межі юридичного \\
банкрутства; усунення наслідків \\
кризи (антикризових заходів) та \\
недопущення їі повторного прояву
\end{tabular} & \begin{tabular}{llr} 
підтримка & та & \multicolumn{2}{c}{ координація } \\
управлінських & дій керівництва 3 \\
попередження & та/або виводу \\
підприємства 3 кризи
\end{tabular} \\
\hline Завдання & 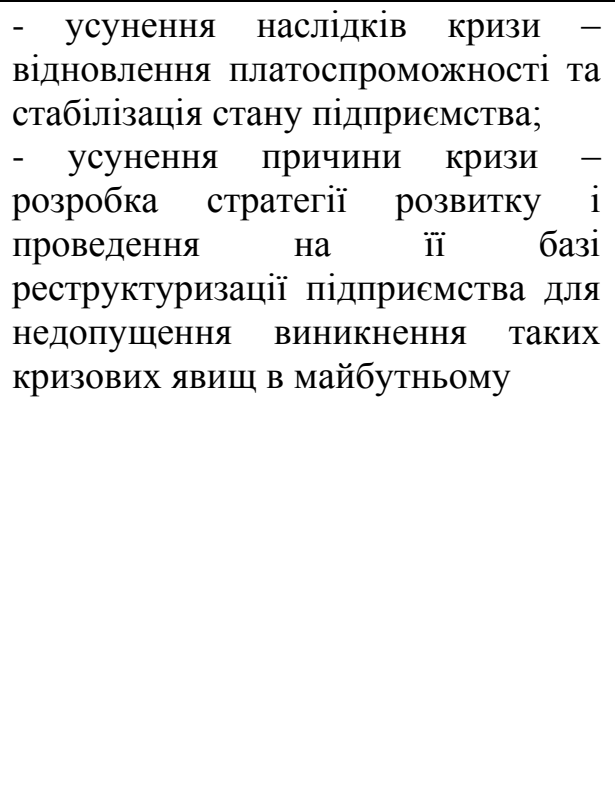 & $\begin{array}{l}\text { - створення системи збору } \\
\text { обробки інформації необхідної для } \\
\text { управління; } \\
\text { - діагностування } \\
\text { техніко-економічного } \\
\text { фінансового стану підприємства; } \\
\text { - порівняння } \\
\text { показників } 3 \text { пактичних } \\
\text { даними; } \\
\text { - виявлення } \\
\text { закономірностей } \\
\text { підприємства; } \\
\text { - пенденцій } \\
\text { впливу внутрішніх та зо зовнішніх } \\
\text { факторів на фінансовий результат } \\
\text { діяльності підприємства; } \\
\text { забезпечення стійкого положення } \\
\text { підприємства на ринку }\end{array}$ \\
\hline
\end{tabular}




\begin{tabular}{|c|c|c|}
\hline 1 & 2 & 3 \\
\hline Функції & $\begin{array}{l}\text { - планування - це процес визначення } \\
\text { цілей організації та їх змін, стратегій і } \\
\text { програм антикризової стабілізації, } \\
\text { ресурсів для ї досягнення; } \\
\text { - організація - формування } \\
\text { оптимальної структури й обсягу } \\
\text { використовуваних коштів, апарату } \\
\text { управління і кадрів для ефективного } \\
\text { використання трудових, матеріальних і } \\
\text { фінансових ресурсів; } \\
\text { - мотивація - система заохочень і } \\
\text { санкцій, що стимулює зацікавленість } \\
\text { всього колективу і кожного працівника } \\
\text { у зростанні ефективності діяльності } \\
\text { підприємства з метою найшвидшого } \\
\text { виходу з кризи; } \\
\text { - контроль - прогнозування відхилень } \\
\text { від намічених цілей для своєчасного } \\
\text { оперативного з внесення } \\
\text { спрямованих змін, } \\
\text { ефективності антикризових заходів }\end{array}$ & $\begin{array}{l}\text { - попереднє планування цілей та } \\
\text { засобів; } \\
\text { - розробка варіантів вирішення, } \\
\text { зокрема, аналіз альтернатив, } \\
\text { передумов та наслідків управлінських } \\
\text { рішень; } \\
\text { - облік та інтерпретація даних } \\
\text { контролю (наприклад, у формі } \\
\text { відхилень від бюджету, сигналів } \\
\text { раннього повідомлення тощо); } \\
\text { впровадження результатів, } \\
\text { отриманих в процесі контролю, у } \\
\text { наступний процес планування } \\
\text { (наприклад, формі пропозицій щодо } \\
\text { корегування напрямку розвитку } \\
\text { підприємства) }\end{array}$ \\
\hline Принципи & \multicolumn{2}{|c|}{$\begin{array}{l}\text { - рання діагностика кризових явищ в діяльності підприємства та класифікація їх } \\
\text { за ступенем небезпеки, дослідження основних факторів, що зумовлюють їх } \\
\text { розвиток; } \\
\text { - своєчасність реагування на окремі кризові явища у розвитку підприємства; } \\
\text { - повна реалізація внутрішніх механізмів для ліквідації кризового стану } \\
\text { (реструктуризація, реінжиніринг); } \\
\text { - використання санації підприємства для уникнення банкрутства; } \\
\text { - забезпечення контролю за результатами розроблених заходів з виведення } \\
\text { підприємства із кризи }\end{array}$} \\
\hline Інструменти & 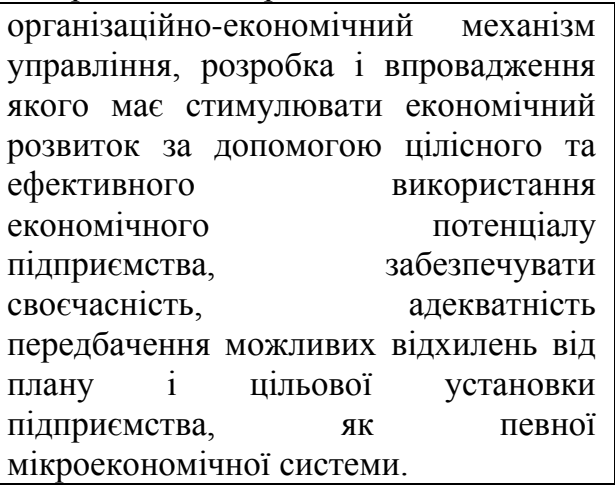 & $\begin{array}{l}\text { - } \quad \text { функціонально-вартісний аналіз; } \\
\text { - } \quad \text { стратегічне управління витратами; } \\
\text { - } \quad \text { сценарний аналіз; } \\
\text { - } \quad \text { матричні аналітичні інструменти; } \\
\text { - } \quad \text { алгоритм розробки за «слабкими» і } \\
\text { «сильними» сигналами; } \\
\text { - фінансова оцінка стратегічних } \\
\text { планів. }\end{array}$ \\
\hline
\end{tabular}

* Систематизовано автором на підставі $[1,3,5,7,8,9]$

Як можна побачити з узагальнюючої таблиці, основною метою антикризового управління є збереження поточного стану розвитку підприємства; недопущення прояву чи загострення кризи, а стратегічний контролінг повинен підтримати досягнення мети через координацію управлінських дій керівництва 3 попередження та/або виводу підприємства 3 кризи. Завданнями антикризового управління $\epsilon$ усунення причин та наслідків кризи на результати діяльності підприємства. Стратегічний контролінг в даному випадку $\epsilon$ інструментом антикризового управління через створення системи збору й обробки інформації необхідної для управління, формування ключових базових показників які характеризують зміну результатів діяльності, визначення їх змін та, на підставі цього, виявлення тенденцій i закономірностей розвитку підприємства. 
В управлінні діяльністю підприємства принципи, які притаманні антикризовому управлінню співпадають 3 принципами стратегічного контролінгу, що підтверджує ствердження про необхідність впровадження стратегічного контролінгу в систему антикризового управління підприємством, та розглядати його як інструмент за допомогою якого можливо передбачати та попереджувати вплив кризових явищ на діяльність підприємства.
Але, ефективність використання стратегічного контролінгу залежить, насамперед, від реальної готовності керівництва підприємства до нього ще до початку самого впровадження, на стадії виникнення загрозливих ознак кризових явищ макрорівня. Місце стратегічного контролінгу в системі антикризового управління підприємством представлено на рисунку.

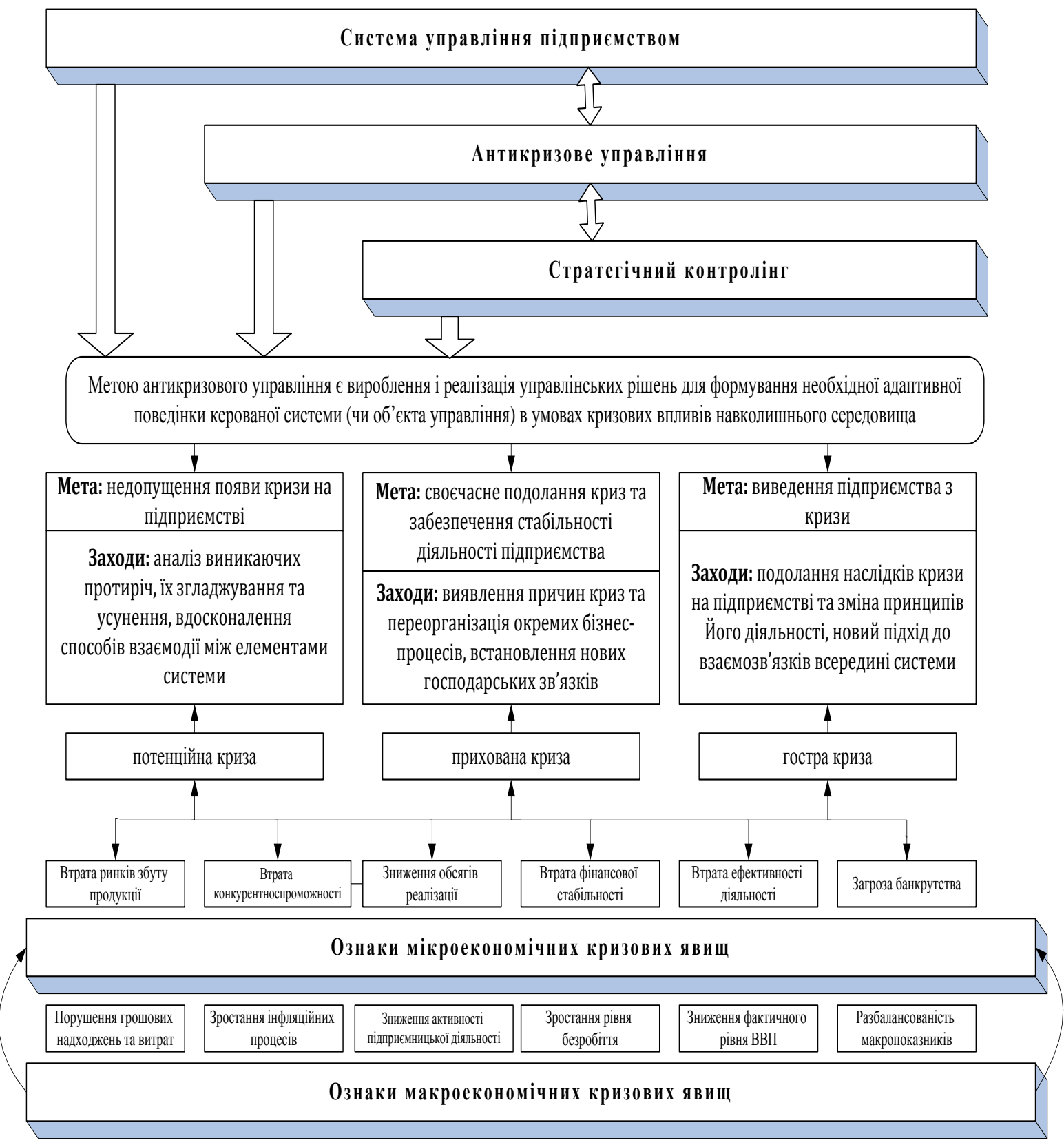

Рис. Місие стратегічного контролінгу в системі антикризового управління підприємством. Складено автором на підставі $[5,7,8,10]$ 
При визначенні місця стратегічного контролінгу в системі антикризового управління підприємством необхідно враховувати вид існуючої кризи (потенційна, прихована, гостра), які характеризуються тим чи іншим ступенем ознак макро та макрорівнів. Відповідно цього необхідним $є$ застосування саме інструментів стратегічного контролінгу, до яких загалом відносять: функціонально-вартісний аналіз; стратегічне управління витратами; сценарний аналіз; матричні аналітичні інструменти; алгоритм розробки за «слабкими» і «сильними» сигналами; фінансова оцінка стратегічних планів, - за допомогою яких безпосередньо можливо попередження кризових умов в діяльності підприємства.

Висновок. Результати діяльності будь-якого підприємства багато в чому залежить від системи управління ним. Кризисні умови господарювання всіх рівнів національної економіки потребують впровадження в систему управління заходів та напрямів антикризового управління, які б надали можливості підприємствам бути більш адаптованими до сучасних умов.

Одним із заходів адаптації до кризових умов господарювання в системі антикризового управління $є$ впровадження системи контролінгу, й однієї 3 іiї складових - стратегічного контролінгу. В дослідженні проведено порівняльну характеристику основних елементів системи антикризового управління та місця стратегічного контролінгу як складової ऑï частини: мети, завдання, функцій, принципів та їх інструментів. Доведено, що й система антикризового управління, й стратегічний контролінг мають спільні принципи управління, функції та спрямовані на досягнення єдиної мети функціонування підприємств в кризових умовах господарювання, а саме: збереження поточного стану розвитку підприємства; недопущення прояву чи загострення кризи.
Таким чином, стратегічний контролінг має стати одним 3 дієвих інструментів антикризового управління в загальній системі управління підприємством, вирішуючи питання адаптації функціонування підприємств в кризових умовах.

\section{ПЕРЕЛІК ВИКОРИСТАНИХ ДЖЕРЕЛ}

1. Великий, Ю.М. Управління витратами підприємства: монографія / Ю.М. Великий, В.В. Прохорова, Н.В. Сабліна. - Х.: ВД «ІНЖЕК», 2009. - 192 с.

2. Ковалёв, А. Актуальные вопросы банковского кризис-менеджмента / А. Ковалёв // Финансовый Директор. 2007. - №11. - С. 15-22.

3. Коваленко, В.В. Антикризове фінансове управління в системі суб'єктів економічної діяльності: методи та інструменти оцінювання [Текст]: монографія/ В.В. Коваленко, М.В. Суганяка, В.І. Фучеджи. - Одеса: 2013. $381 \mathrm{c.}$

4. Коротков Э. М. Антикризисное управление / Э. М. Коротков. - М. : ИНФРА-М, 2003. - 432 с.

5. Мельниченко, О.О. Сутність антикризового управління підприємством у сучасних умовах господарювання [Текст] / О.О.Мельниченко // Економічний аналіз : зб. наук. праць / Тернопільський національний економічний університет; редкол.: В.А. Дерій (голов. ред.) та ін. Тернопіль: Видавничо-поліграфічний центр Тернопільського національного економічного університету «Економічна думка», 2015. - Том 21. - № 2. - С. 157162.

6. Партин, Г.О. Фінансовий менеджмент: навч. посіб. / Г.О.Партин, Н.Є. Селюченко. - Львів: Вид-во НУ «ЛП», 2010. - 332 c.

7. Прохорова, В.В. Концептуальні основи управління потенціалом конкурентоспроможності

машинобудівних підприємств на засадах контролінгу/ В.В. Прохорова, В.I. Чобіток 
// Проблеми системного підходу в економіці. - 2011. - № 39- С. 99-104.

8. Ходзицька, В.В. Стратегічний контролінг як методичний інструментарій стратегічного управління витратами / В.В. Ходзицька // Облік і фінанси, №4 (66), 2014. - C. 146-153.

9. Ус, Ю.В. Формування механізму управління конкурентоспроможністю підприємства / Ю.В. Ус,. А.О. Михнюк // Научно-практический журнал «Экономика и управление». - № 2 - 2014. - С.65-68

10. Якименко-Терещенко, Н.В. Антикризове управління промисловими підприємствами / Н.В. ЯкименкоТерещенко, О.I. Палієнко // «Молодий вчений», № 5.1 (57.1) травень, 2018 р.

\section{REFERENCES}

1. Velykyj, Ju.M. Prokhorova V.V., Sablina N.V. (2009) Upravlinnja vytratamy pidpryjemstva: monoghrafija [Enterprise Cost Management: Monograph]. Kh.: VD "INZHEK". (in Ukrainian)

2. Kovalev A. (2007) Aktual'nye voprosy bankovskogo krizis-menedzhmenta [Current Issues of Banking Crisis Management]. Finance Director. Vol. 11, pp. 15-22

3. Kovalenko V.V., Sughanjaka M.V., Fuchedzhy V.I. (2013) Antykryzove finansove upravlinnja $v$ systemi sub'jektiv ekonomichnoji dijaljnosti: metody ta instrumenty ocinjuvannja: monoghrafija [Anti-crisis financial management in the system of subjects of economic activity: methods and tools of evaluation: monograph]. Odessa. (in Ukrainian)

4. Korotkov E. M. (2003) Antikrizisnoe upravlenie [Crisis Management]. M.: INFRA - M. (in Russian)
5. Meljnychenko, O.O. (2015) Sutnistj antykryzovogho upravlinnja pidpryjemstvom u suchasnykh umovakh ghospodarjuvannja [The essence of crisis management of the enterprise in modern economic conditions]. Economic analysis: Sb. sciences works. Vol. 21, no. 2, pp. 157162

6. Partyn Gh.O., Seljuchenko N.Je. (2010) Finansovyj menedzhment: navch. posib. [Financial Management: Teaching. manual]. Lviv: View of NU "LP" (in Ukrainian)

7. Prokhorova V.V., Chobitok V.I. (2011) Konceptualjni osnovy upravlinnja potencialom konkurentospromozhnosti mashynobudivnykh pidpryjemstv na zasadakh kontrolinghu [Conceptual framework for managing the competitiveness of machine-building enterprises on the basis of controlling]. Problems of a systemic approach in the economy. No.39, pp. 9-104

$$
\text { 8. Khodzycjka, V.V. }
$$

Strateghichnyj kontrolingh jak metodychnyj instrumentarij strateghichnogho upravlinnja vytratamy [Strategic Controlling as a Methodological Toolkit for Strategic Cost Management]. Accounting and finance. No. 4 (66), pp. 146-153

9. Us Ju.V., Mykhnjuk A.O. (2014) Formuvannja mekhanizmu upravlinnja konkurentospromozhnistju pidpryjemstva [Formation of a mechanism for managing the competitiveness of the enterprise]. Scientific and practical journal "Economics and Management". No. 2, pp. 65-68

10. Jakymenko-Tereshhenko N.V., Palijenko O.I. (2018) Antykryzove upravlinnja promyslovymy pidpryjemstvamy [Anti-freeze management of industrial enterprises]. Young scientist. No. 5.1 (57.1). 